\title{
Defective processing of methylated single-stranded DNA by $E$. coli alkB mutants
}

\author{
Suneet Dinglay, Sarah C. Trewick, Tomas Lindahl, and Barbara Sedgwick ${ }^{1}$ \\ Imperial Cancer Research Fund, Clare Hall Laboratories, South Mimms, Hertfordshire EN6 3LD, UK
}

Escherichia coli alkB mutants are very sensitive to DNA methylating agents. Despite these mutants being the subject of many studies, no DNA repair or other function has been assigned to the AlkB protein or to its human homolog. Here, we report that reactivation of methylmethanesulfonate (MMS)-treated single-stranded DNA phages, M13, f1, and G4, was decreased dramatically in alkB mutants. No such decrease occurred when using methylated $\lambda$ phage or M13 duplex DNA. These data show that alkB mutants have a marked defect in processing methylation damage in single-stranded DNA. Recombinant AlkB protein bound more efficiently to single- than double-stranded DNA. The single-strand damage processed by AlkB was primarily cytotoxic and not mutagenic and was induced by SN2 methylating agents, MMS, DMS, and MeI but not by SN1 agent $N$-methyl- $N$-nitrosourea or by $\gamma$ irradiation. Strains lacking other DNA repair activities, alkA tag, $x$ th $n$ fo, uvrA, mutS, and umuC, were not defective in reactivation of methylated M13 phage and did not enhance the defect of an alkB mutant. A recA mutation caused a small but additive defect. Thus, AlkB functions in a novel pathway independent of these activities. We propose that AlkB acts on alkylated single-stranded DNA in replication forks or at transcribed regions. Consistent with this theory, stationary phase alkB cells were less MMS sensitive than rapidly growing cells.

[Key Words: DNA repair; DNA alkylation; AlkB]

Received March 27, 2000; revised version accepted June 15, 2000.

Alkylating agents arise endogenously in cells and also occur widely in the environment (Rebeck and Samson 1991; Vaughan et al. 1991; Taverna and Sedgwick 1996). As a consequence, cells need protection against such compounds, which is provided by activities that specifically remove alkylation lesions from DNA. Inducible resistance of Escherichia coli to the cytotoxic and mutagenic effects of simple alkylating agents involves the increased expression of the $a d a, a l k A$, and $a l k B$ genes (Lindahl et al. 1988). The functions of the Ada and AlkA proteins have been studied in detail, whereas that of AlkB remains unclear. Ada, a multifunctional protein, directly demethylates $\mathrm{O}^{6}$-methylguanine and methylphosphotriesters in DNA by transferring methyl groups onto two of its own cysteine residues. It also positively regulates the adaptive response using $S$-diastereoisomers of methylphosphotriesters as the inducing signal (Lindahl et al. 1988). AlkA is a 3-methyladenineDNA glycosylase and excises the toxic lesion 3-methyladenine from DNA. It can also excise other altered bases, such as hypoxanthine and $\mathrm{N}^{6}$-ethenoadenine (Matijasevic et al. 1992; Saparbaev and Laval 1994). The resulting abasic sites are repaired by the base excision repair pathway (Lindahl et al. 1997). $\mathrm{O}^{6}$-methylguanine-DNA methyltransferases and 3-methyladenine-DNA glyco-

${ }^{1}$ Corresponding author.

E-MAIL b.sedgwick@icrf.icnet.uk; FAX 171-269-3801 sylases are conserved in prokaryotes and eukaryotes (Pegg et al. 1995). An additional E. coli function, AidB, is induced by high concentrations of alkylating agents and is possibly involved in inactivation of certain alkylating agents (Landini et al. 1994).

Conservation of AlkB protein from bacteria to humans indicates its importance for cellular defence against alkylating agents (Wei et al. 1996), but its function remains elusive despite its identification in 1983 (Kataoka et al. 1983). The alkB gene forms a small operon with $a d a$ and is regulated from the $a d a$ promoter (Lindahl et al. 1988). The AlkB protein prevents death from cells' exposure to methylmethanesulfonate (MMS) and dimethylsulphate (DMS) but is less effective in protection against $\mathrm{N}$-methyl-N'-nitro-N-nitroguanidine (MNNG) and $N$-methyl- $N$-nitrosourea (MNU; Kataoka et al. 1983; Chen et al. 1994). A small defect in the reactivation of MMS-treated $\lambda$ bacteriophage in an alkB mutant suggests a role for AlkB in DNA repair (Kataoka et al. 1983), but the mechanism is unknown. AlkB mutants are not defective in the repair of several different types of potentially toxic lesions that may be generated by methylating agents in duplex DNA. These lesions include 3-methyladenine, DNA strand breaks, abasic sites, and secondary lesions that may arise at abasic sites such as DNAprotein cross-links and DNA interstrand cross-links (Dinglay et al. 1998). Purified AlkB protein is devoid of detectable DNA glycosylase, DNA methyltransferase, 
nuclease, or DNA-dependent ATPase activity in standard enzyme assays (Kondo et al. 1986) and has no sequence similarity to other proteins of known function in the databases. Homologs of AlkB have been identified in Homo sapiens and Caulobacter crescentus (Wei et al. 1996; Colombi and Gomes 1997), and recent database searches reveal a wide distribution of other putative AlkB homolog through evolution (data not shown). Overexpression of the E. coli AlkB protein confers MMS resistance to human cells (Chen et al. 1994), and conversely, the human protein confers alkylation resistance to $E$. coli alkB mutants (Wei et al. 1996), suggesting that AlkB proteins act independently and not via formation of multiprotein complexes. Expression of the $C$. crescentus alk $B$ gene is not induced by alkylation damage but is cell-cycle regulated with a pattern similar to activities required for DNA replication (Colombi and Gomes 1997).

In this article, we describe a substantial defect in the reactivation of MMS-treated single-stranded DNA phages in alkB mutants and show that AlkB protein is required to process toxic DNA damage induced in singlestranded DNA by SN2 methylating agents.

\section{Results}

\section{AlkB processes methylated single-stranded DNA}

AlkB mutants are sensitive to killing by MMS but only marginally sensitive to MNNG. They have a small defect in the reactivation of MMS-treated $\lambda$ phage, indicating a defect in DNA repair (Kataoka et al. 1983). Differences in the known spectra of methylated bases induced by MMS and MNNG were considered as a possible explanation for the alkB phenotype. The sites methylated by MMS in duplex DNA are also modified by MNNG, whereas in single-stranded DNA some sites are more reactive with MMS than with MNNG (Singer and Grunberger 1983). To examine the possibility that the AlkB protein processes damage induced in single-stranded DNA, reactivation of MMS-treated M13 phage was monitored in an alkB117::Tn3 mutant. Survival of the methylated phage was strikingly low in the alkB mutant. The lethal MMS dose resulting in 10\% M13 survival (LD10) was fourfold lower for the alk $B$ mutant than for the wild type (Fig. 1A). The survival of untreated phage was the same in both strains. Similar observations were made using two other single-stranded DNA phages, $\mathrm{f} 1$ and G4, when they were treated with MMS and transfected into alkB117::Tn3 mutants (Fig. 1B,C), whereas no similar defect was apparent in the reactivation of MMStreated $\lambda$, a double-stranded DNA phage (Fig. 1D). The pronounced defect in reactivation of MMS-treated M13 was also observed in a second alk $B$ mutant, HK82 (alkB22; data not shown). These observations indicate that the AlkB protein is required specifically to process damaged single-stranded DNA or lesions formed more frequently in single strands but recognized in both single or duplex DNA.

Instead of using intact phage, purified M13 DNA in
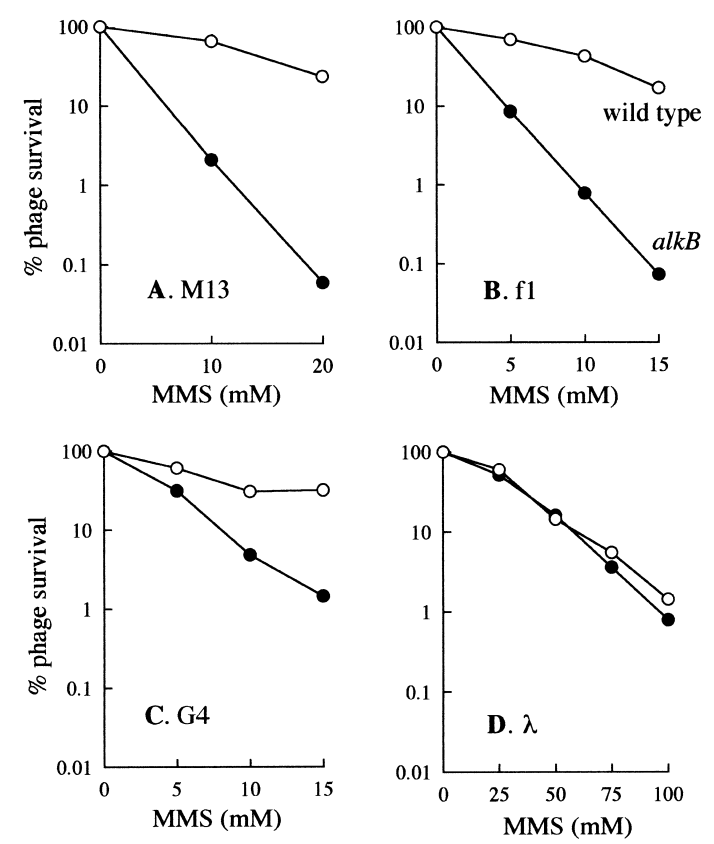

Figure 1. Defective reactivation of MMS-treated singlestranded DNA phages in an alkB mutant. Phages M13, f1, and G4 were treated with various doses of $M M S$ at $30^{\circ} \mathrm{C}$ for $30 \mathrm{~min}$ and immediately plated to estimate survival in wild type (O) and alkB117::Tn3 $(\bullet)$ strains. Double-stranded DNA phage $\lambda$ was similarly treated but at $37^{\circ} \mathrm{C}$. $(A) \lambda$ phage were plated on AB1157 (wild type) and BS87 (alkB117::Tn3); (B) M13 and (C) f1 phage, on $\mathrm{AB} 1157 / \mathrm{F}^{\prime}$ and $\mathrm{BS} 87 / \mathrm{F}^{\prime} ;(D)$ G4 phage on Escherichia coli C-1 and BS159 (E. coli C-1 but alkB117::Tn3).

its duplex or single-stranded form was treated with MMS, transformed by heat shock into wild type and alkB117::Tn3 strains and plaque-forming units were monitored. The transformation efficiency of MMStreated single-stranded DNA was markedly less in the alk $B$ mutant than in the wild type, the LD50 being fivefold less in the alkB mutant (Fig. 2B). In contrast, doublestranded M13 DNA treated with up to 100 mM MMS transformed wild type and alkB strains with equal frequencies and decreased by less than twofold in both strains (Fig. 2A). These observations confirmed that AlkB is required to process methylation lesions in singlestranded DNA.

\section{AlkB preferentially binds to single-stranded DNA}

To tag the AlkB protein at its amino terminus with six histidines, the $a$ lk $B$ gene was subcloned into a pET15b vector (Studier et al. 1990). Expression of the subcloned gene was IPTG (isopropyl $\beta$-D-thiogalactoside) inducible. The new plasmid construct, pBAR54, complemented MMS sensitivity of an alkB mutant, demonstrating that the his-tagged AlkB protein was active in vivo (data not shown). The his-tagged protein was purified by Ni-NTA-agarose column chromatography (Fig. 3A), and its binding affinities to single-stranded and duplex DNA in nonmethylated and methylated forms were compared. 

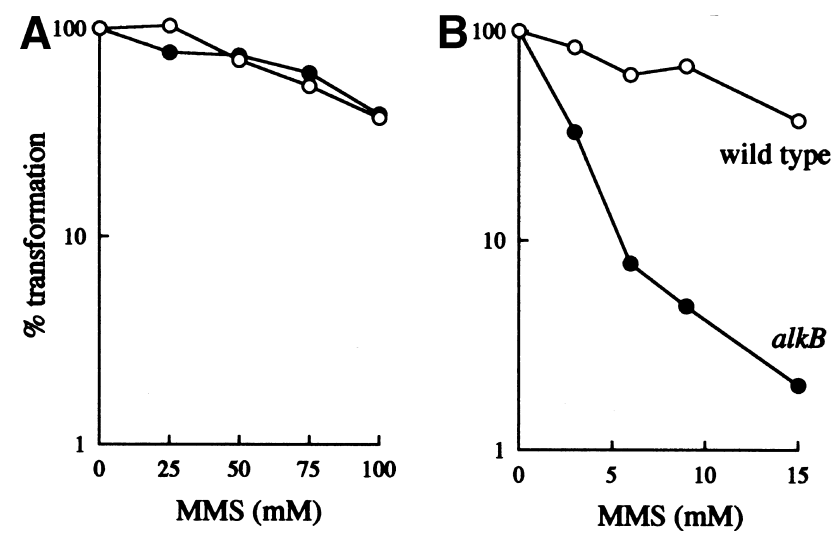

Figure 2. Decreased frequency of transformation by MMS treated single-stranded M13 DNA in an alkB mutant. M13 DNA, $20 \mathrm{ng}$ double stranded or $100 \mathrm{ng}$ single stranded, treated with MMS at various concentrations at $30^{\circ} \mathrm{C}$ for $30 \mathrm{~min}$ was transformed into AB1157 (wild type; O) and BS87 (alkB117::Tn3; @) strains. (A) Double-stranded M13 DNA; (B) Single-stranded M13 DNA.

The purified protein was incubated with $5^{\prime}-{ }^{32} \mathrm{P}$ end-labeled 40-mer oligonucleotides, and binding was monitored by nitrocellulose filter binding assays. AlkB protein bound to both single- and double-stranded DNA but showed a much greater affinity for single-stranded DNA. Preferential binding of AlkB to single-stranded DNA was also confirmed using a gel-shift assay (Ausubel et al. 1999; data not shown). Pretreatment of the single- and double-stranded substrates with a high dose of MMS 1300 $\mathrm{mM}$ ) increased the AlkB binding affinity by approximately twofold in both cases (Fig. 3B). However, a similar increase of approximately 2.5 -fold was also observed on pretreatment of the single-stranded DNA with 300 mM MNU (data not shown). AlkB mutants are not especially sensitive to MNU (Kataoka et al. 1983), so the stimulation by high doses of these two methylating agents may reflect altered structural properties of the heavily alkylated DNA rather than a binding to a specific lesion processed by AlkB.

\section{AlkB processes DNA damage induced by SN2 methylating agents}

SN1 and SN2 alkylating agents react through unimolecular and bimolecular pathways of nucleophilic substitution, respectively. AlkB mutants are sensitive to SN2 methylating agents, MMS and DMS, but much less sensitive to SN1 agents, MNNG and MNU (Kataoka et al. 1983; Chen et al. 1994). To ascertain whether this characteristic also applies to the survival of single-stranded DNA phage in an alkB mutant, reactivation of M13 after treatment with DMS, methyl iodide (MeI, also an SN2 agent), MNU, or $\gamma$ rays was examined in $\mathrm{AB} 1157 / \mathrm{F}^{\prime}$ (wild type) and BS87/F' (alkB117::Tn3) strains. After exposure to DMS or MeI, M13 survival was much lower in the alkB mutant compared with the wild type strain, whereas after treatment with MNU or $\gamma$ rays, survival decreased similarly in both strains (Fig. 4). LD10 of DMS was fivefold lower and LD50 of MeI sevenfold lower in the alkB mutant. Thus, damage in single-stranded DNA processed by the AlkB protein is induced specifically by the SN2 agents MMS, DMS, and MeI but not by MNU or $\gamma$ rays.

\section{AlkB function is independent of other DNA repair pathways}

AlkA and Tag are 3-methyladenine-DNA glycosylases that repair the toxic lesion 3-methyladenine. To determine whether these activities influence survival of damaged single-stranded DNA, M13 phage were treated with MMS and their survival was assayed in an alkA tag mutant. This mutant was not defective in reactivating methylated M13 phage, and an alkA tag $\Delta(a d a-a l k B)$ mutant was no more deficient than the single $a l k B \mathrm{mu}-$ tant (Fig. 5A). In contrast, the alkA tag mutant had a striking defect in reactivation of MMS-treated $\lambda$ phage,

$\mathbf{A}$
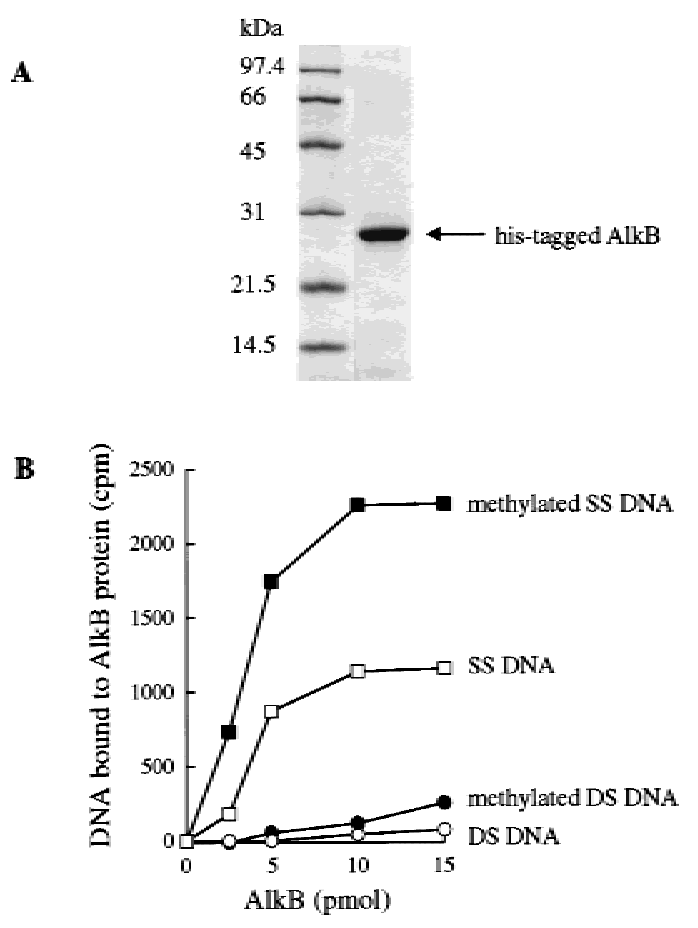

Figure 3. Binding of AlkB to DNA. (A) His-tagged AlkB protein was purified by Ni-NTA-agarose column chromatography and visualized by SDS-polyacrylamide gel electrophoresis and Coomassie blue staining. Sizes of molecular weight markers (kD) are indicated. $(B)^{32} \mathrm{P}-5^{\prime}$-end labeled single- or double-stranded 40-mer oligonucleotides were methylated by treatment with $300 \mathrm{~mm}$ MMS. Various amounts of his-tagged AlkB protein were incubated with these substrates $(30,000 \mathrm{cpm} /$ reaction $)$ at $30^{\circ} \mathrm{C}$ for $30 \mathrm{~min}$. Reaction mixtures were passed through nitrocellulose filters and DNA bound to retained AlkB protein quantitated by scintillation counting. The substrates were $(\square)$ singlestranded DNA; ( $\mathbf{\square}$ methylated single-stranded DNA; (O) double-stranded DNA; $(\mathbf{O})$ methylated double-stranded DNA. 

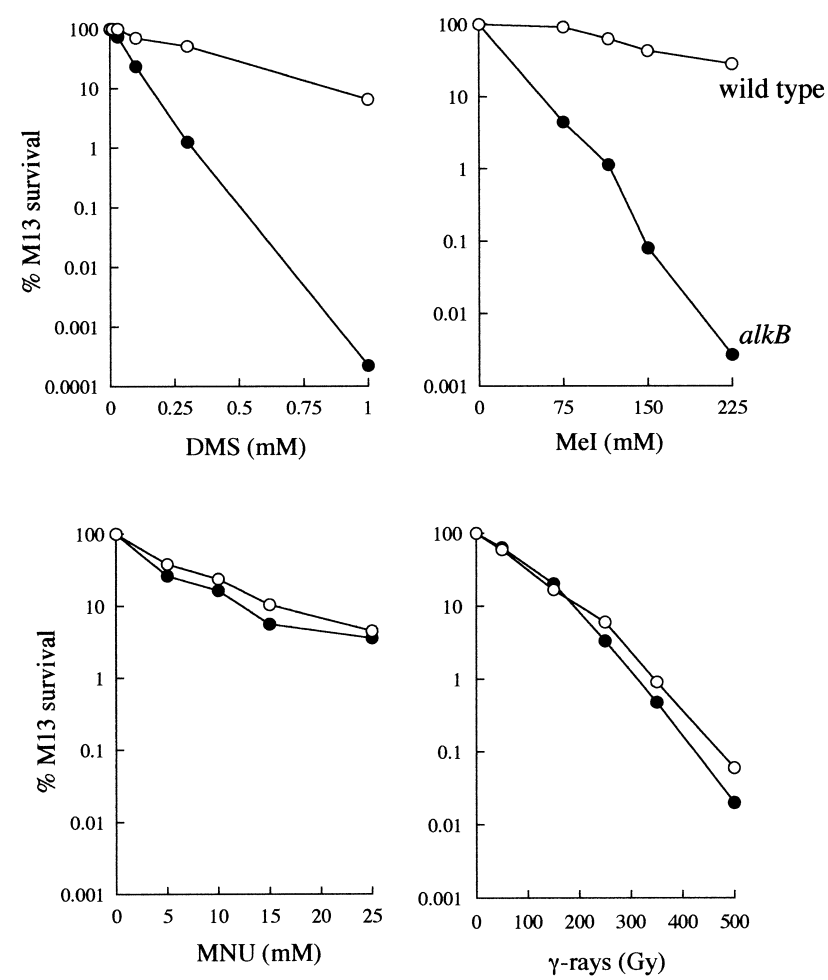

Figure 4. Defective reactivation of DMS and MeI (but not MNU and $\gamma$ rayl treated M13 phage in an alkB mutant. M13 phage were treated with various doses of DMS, MeI, or MNU at $30^{\circ} \mathrm{C}$ for $30 \mathrm{~min}$ or with $\gamma$ rays $(2.71 \mathrm{~Gy} / \mathrm{min})$ for various times and immediately plated to estimate survival in $\mathrm{AB} 1157 / \mathrm{F}^{\prime}$ (wild type; O) and BS87/F' (alkB117::Tn3; O) strains.

whereas an $a l k B$ mutant showed no defect (Fig. 5B). Reactivation of MMS-treated M13 phage was also not defective in $x$ th $n f o$ double mutants lacking apurinic endonucleases or in umuC, uvrA, or mutS mutants defective in error-prone replication, nucleotide excision repair, or mismatch repair (data not shown). A recA mutant showed a small reproducible defect in reactivation of methylated M13 phage, and a $\operatorname{rec} A$ alk $B$ double mutant had a slightly greater defect than an alk $B$ single mutant. The recA and $a l k B$ mutant defects were therefore additive, indicating that the two activities work independently (Fig. 5C).

\section{Processing of mutagenic DNA damage by AlkB}

The effect of AlkB activity on the spectrum of base substitutions induced by MMS was examined. Initially, the frequency of lac $Z$ mutations arising in MMS-treated M13mp18 was analyzed after transfection of $\mathrm{F}^{\prime} /$ wildtype and $\mathrm{F}^{\prime} / a l k B$ strains. The mutation frequencies were low (in the range of $10^{-4}-10^{-5}$ ) but slightly higher in the alk $B$ mutant than in the wild type (data not shown). With the aim of increasing the frequency of base substitution mutations, the SOS response and error-prone replication were induced by direct treatment of cells with MMS (Schendel and Defais 1980; Banerjee et al. 1990).
Six F'lacZ- $Z^{-}$lac strains (CC101-CC106) that revert to $\mathrm{F}^{\prime} l a c Z^{+} / \Delta l a c$, each by different targeted base substitution mutations, were used (Cupples and Miller 1989). Small but reproducible increased frequencies of G:C to A:T, G:C to T:A, and A:T to T:A base substitutions were observed in alkB117::Tn3 derivatives of CC102, CC104, and $\mathrm{CC} 105$, respectively, compared with the relevant wild-type strains (Fig. 6). Other types of base substitutions in alkB derivatives of CC101, CC103, and CC106 were not detected (data not shown). Ada ogt mutants are sensitive to induction of GC to AT transition mutations by DNA methylating agents (Mackay et al. 1994). The alk $B$ mutants were only weakly sensitive to MMS mutagenesis compared with CC102 $\Delta($ ada-alkB) ogt (Fig. 6).

\section{AlkB mutants in stationary phase are less sensitive to $M M S$}

Stationary phase cells have fewer DNA replication forks (Kornberg and Baker 1992) and are less active in transcription than rapidly growing cells and may, therefore, contain fewer regions of single-stranded DNA. Consequently, alkB cells deficient in processing damaged single-stranded DNA may be less sensitive to MMS in
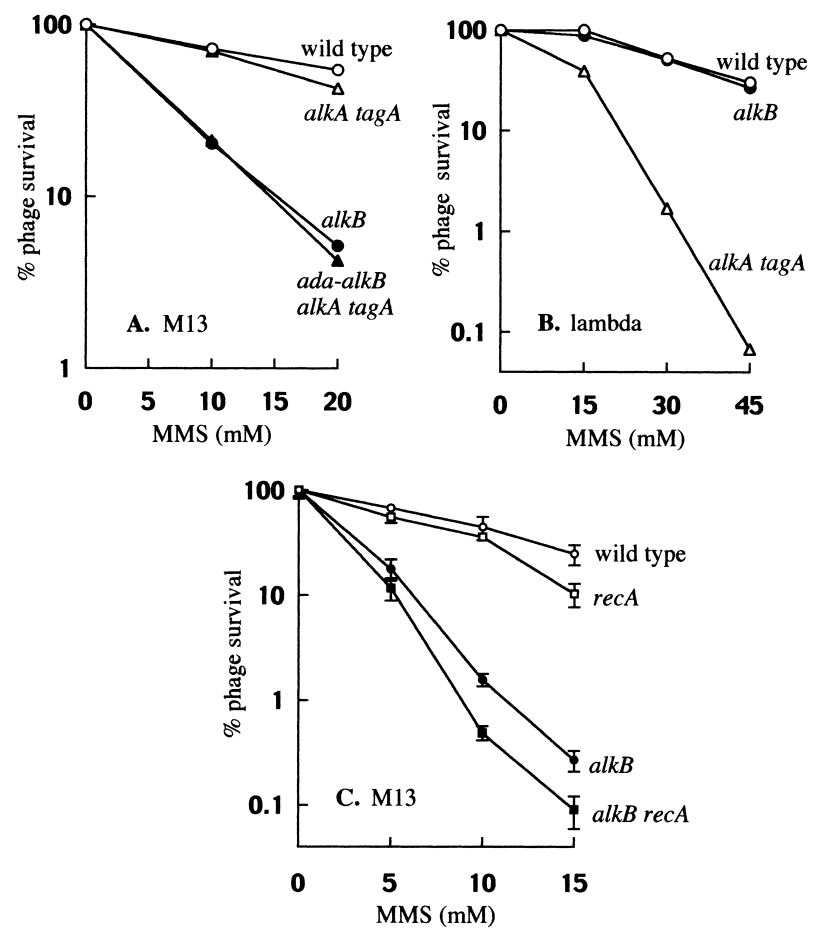

Figure 5. Survival of MMS treated M13 and $\lambda$ phages in alkA tag and recA mutants. The phage were treated with increasing doses of MMS for $30 \mathrm{~min}$ at $23^{\circ} \mathrm{C}(A)$ or $30^{\circ} \mathrm{C}(B, C)$ and immediately plated on various strains. (A) M13 transfection of: (O)

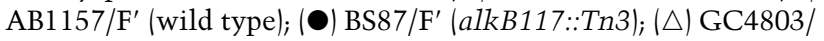

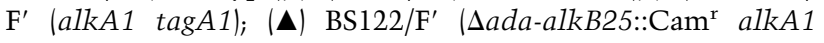
$\operatorname{tag} A 1)$. (B) $\lambda$ Transfection of: (O) AB1157 (wild type); (O) BS87 (alkB117::Tn3); $(\triangle)$ GC4803 (alkA1 tagA1). (C) M13 transfection of: (O) AB1157/F' (wild type); (@) BS87/F' (alkB117::Tn3); $(\square) \mathrm{SD} 4 / \mathrm{F}^{\prime}(\Delta r e c A) ;(\mathbf{\square}) \mathrm{SD} 5 / \mathrm{F}^{\prime}(\Delta r e c A$ alkB117::Tn3). 


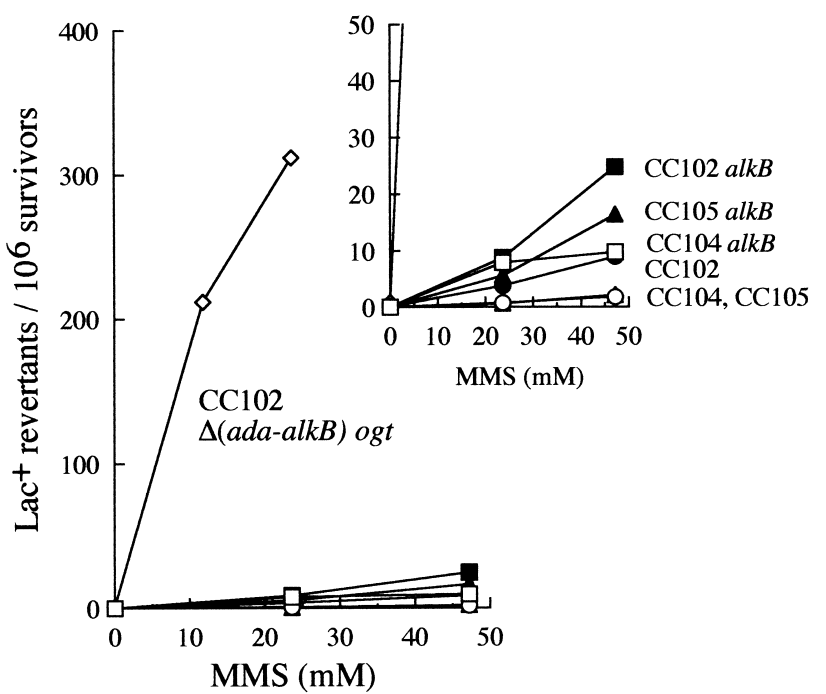

Figure 6. MMS mutagenesis of E. coli alkB mutants. CC101$\mathrm{CC106}\left(\mathrm{F}^{\prime} l a c Z^{-} / \Delta \mathrm{lacZ}\right)$ and their alkB derivatives were treated with increasing concentrations of MMS at $37^{\circ} \mathrm{C}$ for $20 \mathrm{~min}$ and immediately plated to monitor $\mathrm{Lac}^{+}$revertants and survivors.

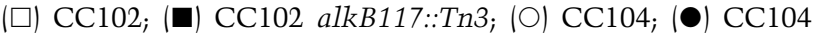

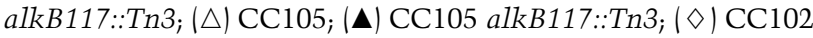
$\Delta\left(\right.$ ada-alkB25)::Cam ${ }^{\mathrm{r}}$ ogt-1::Kan${ }^{\mathrm{r}}$. The same data are displayed on two different scales.

stationary phase than during exponential growth. As expected, exponentially proliferating $a l k B$ cells were much more sensitive to MMS than wild-type cells growing at a similar rate. The MMS sensitivity of alk $B$ cells was significantly reduced when in stationary phase, whereas wild type stationary and exponential cells had only a small difference in sensitivity (Fig. 7A). This latter observation indicated that uptake or reactivity of MMS was not dramatically reduced in stationary phase and so was not the reason for decreased sensitivity of the stationary alk $B$ cells. A difference between exponential and stationary alk $B$ cells was not observed in the reactivation of
MMS-treated M13 phage in agreement with the concept that the reduced sensitivity of $a l k B$ stationary cells to direct MMS treatment is due to a low content of singlestranded DNA sequences (Fig. 7B).

\section{Discussion}

Homologs of the alk $B$ gene have been identified in several bacterial genomes, Schizosaccharomyces pombe, Drosophila melanogaster, Arabidopsis thaliana, and Homo sapiens, but not in Saccharomyces cerevisiae (data not shown; Wei et al. 1996; Colombi and Gomes 1997). Persistence of the AlkB protein through evolution indicates an important functional role in cellular responses to alkylating agents that make up the largest group of environmental genotoxic compounds. No significant homology of AlkB to other known DNA-processing activities has been found by database searches, although a novel hydrolase domain has been suggested (Aravind et al. 1999). Early observations indicated a possible minor role for AlkB in processing damage in methylated duplex DNA (Kataoka et al. 1983). Here, by phage reactivation experiments and cellular transformation with isolated DNA, we observed an extreme deficiency in the ability of $a l k B$ mutants to process methylated single-stranded DNA but little if any defect in processing double-stranded DNA. These observations provide conclusive evidence that AlkB protein processes DNA damage and deals with lesions produced in single-stranded DNA. In addition, we have shown that AlkB binds preferentially to single-stranded DNA. These findings provide crucial steps forward in elucidating the function of the AlkB protein.

The E. coli Tag and AlkA 3-methyladenine-DNA glycosylases excise toxic 3-methyladenine residues from duplex DNA. AlkA protein in vitro can also act on single-stranded DNA but with a low efficiency (Bjelland and Seeberg 1996). By phage reactivation experiments, we found that an alkA tag strain was not defective in processing methylated single-stranded DNA in vivo.
A

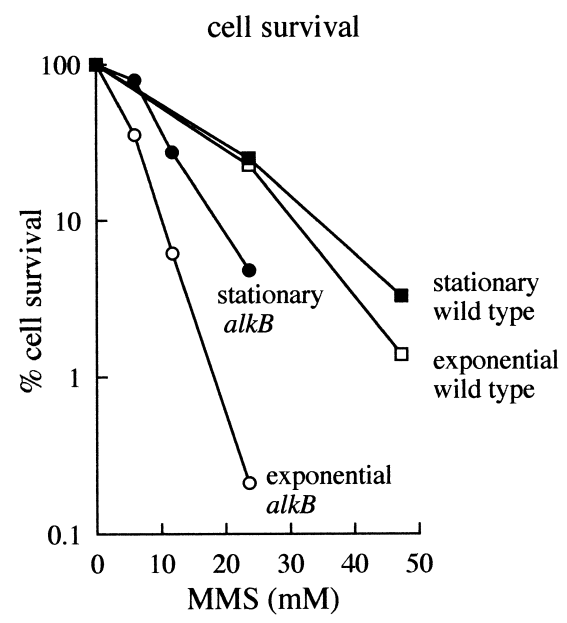

B

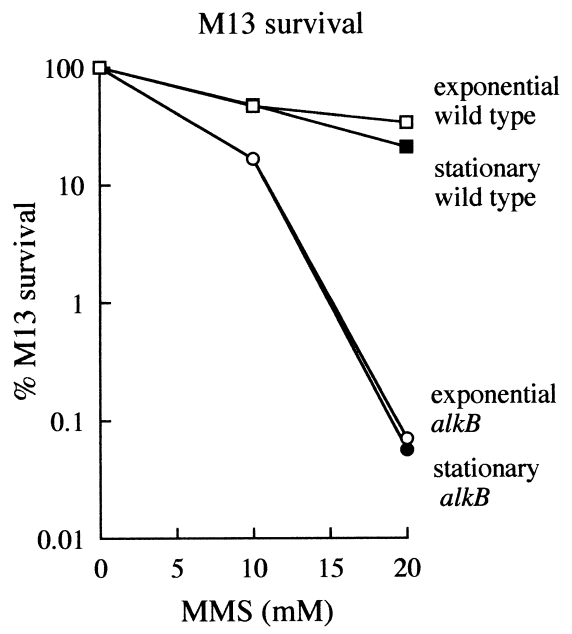

Figure 7. Sensitivity of exponential and stationary phase cells to MMS and their ability to reactivate MMS-treated M13 phage. $(A)$ Exponential cultures $\left(\mathrm{A}_{450} 0.5\right)$ and overnight cultures $\left(\mathrm{A}_{450} 1.3\right)$ that had been in stationary phase for $16 \mathrm{hr}$ were exposed to various concentrations of MMS for $20 \mathrm{~min}$ and then assayed for survival. (B) M13 phage were treated with various concentrations of $\mathrm{MMS}$ at $30^{\circ} \mathrm{C}$ for $30 \mathrm{~min}$ and assayed for survival in the exponential and stationary phase cultures. The titer of untreated phage $1100 \%$ survival) was the same in stationary and exponential cells. ( $\square$ ) Exponential AB1157 (wild type); (ם) stationary AB1157; (O) exponential BS87 (alkB117::Tn3); (O) stationary BS87. 
This observation suggests that AlkA is either not active on DNA single strands in vivo or that the apurinic sites resulting from its activity on single-stranded DNA have a similar toxicity to 3-methyladenine. The alkA tag $\Delta(a d a-a l k B)$ mutant was no more defective in processing single-stranded DNA than the $a 1 k B$ single mutant. Processing of methylated lesions in DNA single strands by AlkB therefore does not involve cooperation with 3-methyladenine-DNA glycosylases. Additive sensitivity of an alkA alkB double mutant to MMS has been noted previously (Volkert and Hajec 1991).

The $a l k B$ mutants investigated were only weakly susceptible to MMS-induced base substitution mutagenesis. Thus, the lesions processed by AlkB in DNA single strands have a low capacity for mispairing during DNA replication. Also, processing of DNA damage by AlkB protein in wild-type strains reduced mutagenesis rather than causing it and, so, is unlikely to involve inaccurate replication past blocking lesions. In addition to this, survival of MMS-treated M13 phage was not reduced in a umuC mutant, indicating that AlkB protein does not cooperate with UmuC to allow replication past the damage. Considering the possibility that AlkB may be involved in accurate lesion bypass, it is of note that the survival of MMS-treated M13 phage was not reduced in $x$ th $n f_{O}$ or uvrA mutants. Base excision or nucleotide excision repair therefore do not excise the damage from double-stranded DNA after lesion bypass events. A recA mutant had a small defect in processing methylated single-stranded DNA. Our evidence indicated that AlkB and RecA proteins act in different processes and, therefore, RecA may provide a minor alternative pathway for dealing with the damage in single-stranded DNA.

A unique characteristic of $a l k B$ mutants is their extreme sensitivity to SN2 but not SN1 methylating agents (Kataoka et al. 1983). Here, the cytotoxic lesions processed by AlkB in single-stranded DNA were similarly induced by several SN2 methylating agents, DMS, MMS, and MeI, but not by the SN1 agent MNU or by $\gamma$ irradiation. Both SN1 and SN2 methylating agents induce $\mathrm{N}^{7}$-methylguanine and $\mathrm{N}^{3}$-methyladenine in single-stranded DNA (Singer and Grunberger 1983). Modification at these sites destabilizes the glycosyl bond, and any base loss results in toxic apurinic sites. Since MNU does not induce the lesions that are processed by AlkB protein but does induce $\mathrm{N}^{7}$-methylguanine, $\mathrm{N}^{3}$-methyladenine, and apurinic sites, these lesions were excluded as substrates of AlkB. The observation that $\mathrm{AlkB}$ protein processes damaged singlestranded DNA also eliminates DNA interstrand crosslinks as its substrate. Our attention was drawn to sites that are normally protected from methylation by hydrogen bonding in duplex DNA but that are more reactive in single-stranded DNA. Thus, $\mathrm{N}^{1}$-methyladenine and $\mathrm{N}^{3}$ methylcytosine are induced by MMS more readily in single than double strands, and this effect is less pronounced for MNU (Singer and Grunberger 1983). N ${ }^{3}$. methylcytosine residues block DNA replication in vitro, and this may also be the case for $\mathrm{N}^{1}$-methyladenine because of disruption of base pairing and inability to form stable base pairs (Abbott and Saffhill 1977; Boiteux and Laval 1982; Saffhill 1984; Larson et al. 1985). Because of their potential cytotoxicity, we propose these lesions as candidate substrates for the AlkB protein. However, active removal of radiolabeled $\mathrm{N}^{1}$-methyladenine or $\mathrm{N}^{3}$ methylcytosine promoted by AlkB from cellular DNA in vivo or from DNA substrates by purified AlkB protein has not been detected (data not shown). Also, the spectrum of base substitution mutations in an MMS-treated alk $B$ mutant did not point to a particular modified base as the substrate of AlkB. The mutation frequencies for three out of six possible substitutions showed a small increase, but the mutations occurred in both GC and AT base pairs.

The specificity of AlkB protein in processing damage in DNA single strands suggests that AlkB acts at DNA replication forks or at sites of transcription. This model is supported by the observation that rapidly growing AlkB cells are more sensitive to MMS than those in stationary phase, whereas the growth stage of the cells did not affect survival of MMS-treated M13 phage. Lesions that arise in the replication fork and block DNA synthesis will require rapid repair or bypass replication. We propose that $\mathrm{AlkB}$ is involved in either of these processes functioning in an apparently accurate manner and playing a similar critical role in the cellular defence against methylating agents both in E. coli and mammalian cells.

\section{Materials and methods}

\section{Materials}

MMS, DMS, and MeI were purchased from Aldrich; M13mp18 RF1 DNA from Pharmacia Biotech; and MNU was a kind gift from P. Swann, University College London.

\section{Bacterial strains}

E. coli strains are listed in Table 1. New E. coli K12 strains were constructed by transduction using P1 cml clr 100 bacteriophage (Sedgwick 1982). The alkB117::Tn3, $\Delta\left(\right.$ ada-alkB25::Cam ${ }^{\mathrm{r}}$ ), and $\Delta(\operatorname{srlR}$-recA)306::Tn10 transductants were selected on LB agar containing $50 \mu \mathrm{g} / \mathrm{ml}$ carbenicillin, $20 \mu \mathrm{g} / \mathrm{ml}$ chloramphenicol, or $15 \mu \mathrm{g} / \mathrm{ml}$ tetracyline, respectively. Enhanced MMS sensitivity of $a l k B$ transductants compared with the parent strains was verified by streaking $10 \mu \mathrm{l}$ of cultures $\left(\mathrm{A}_{450} 0.4\right)$ across a gradient of 0-11.8 mM MMS in a $10-\mathrm{cm}$ square Luria-Bertani (LB) agar plate and incubating at $37^{\circ} \mathrm{C} . \mathrm{F}^{\prime}$ pro $A B^{+}$lacI ${ }^{\mathrm{Q}}$ lacZ $\Delta M 15$ Tn10 was transferred from XL1-Blue (Stratagene) into several strains and selected by plating on LB agar containing $15 \mu \mathrm{g} / \mathrm{ml}$ tetracycline and $200 \mu \mathrm{g} / \mathrm{ml}$ streptomycin for counterselection. Most $\mathrm{F}^{\prime}$ strains used in M13 and $\mathrm{f} 1$ phage survival and mutagenesis experiments contained this $\mathrm{F}^{\prime}$ factor. The exceptions were $\Delta(\mathrm{srlR}$ recA)306::Tn10 strains that carried $\mathrm{F}^{\prime}$ proAB $B^{+}$lacI ${ }^{\mathrm{Q}}$ lacZ $\Delta M 15$ Tn5 (Stratagene) selected on $40 \mu \mathrm{g} / \mathrm{ml}$ kanamycin. F' 148 (his $^{+}$aroD $^{+}$) was transferred from KLF48/KL159 (Coli Genetic Stock Center) into BS87 (alkB117::Tn3) and selected by plating on M9 minimal agar supplemented with $20 \mu \mathrm{g} / \mathrm{ml}$ required amino acids except histidine and $50 \mu \mathrm{g} / \mathrm{ml}$ carbenicillin. F'148/BS87 was then used to transfer the alkB117::Tn3 mutation into E. coli C-1 by $\mathrm{F}^{\prime}$-mediated transfer (Miller 1972), and BS159 (E. coli C-1 
Table 1. E. coli K12 and E. coli C strains

\begin{tabular}{|c|c|c|}
\hline Strain & Genotype & Source or derivation \\
\hline $\mathrm{AB} 1157$ & $\begin{array}{l}\text { argE3 hisG4 leuB6 } \Delta(g p t-p r o A) 62 \text { thr-1 ara-14 } \\
\text { galK2 lacY1 mtl-1 xylA5 thi-1 rpsL31 glnV44 tsx-33 } \\
\text { rfbD1 mgl-51 kdgK51 }\end{array}$ & Laboratory stock \\
\hline BS87 & as $\mathrm{AB} 1157$ but alkB117::Tn3 & Sedgwick 1992 \\
\hline GW7107 & as $\mathrm{AB} 1157$ but $\Delta\left(\right.$ ada-alkB25)::Cam ${ }^{\mathrm{r}}$ & G.C. Walker \\
\hline GC4803 & as $\mathrm{AB} 1157$ but $\mathrm{X}:: \operatorname{Tn} 5 \operatorname{tag} A 1$ alkA1 & S. Boiteux \\
\hline BS122 & as GC4803 but $\Delta\left(\right.$ ada-alkB25)::Cam ${ }^{\mathrm{r}}$ & P1(GW7101)xGC4803 \\
\hline RPC501 & as $\mathrm{AB} 1157$ but $n f o-1:: \operatorname{Kan}^{\mathrm{r}} \Delta x t h$ & B. Weiss \\
\hline BS121 & RPC501 but $\Delta\left(\right.$ ada-alkB25)::: $\mathrm{Cam}^{\mathrm{r}}$ & P1(GW7101)xRPC501 \\
\hline RW202 & trpE65 lon-11 sulA1 $\Delta($ srlR-recA)306::Tn10 & B. Bridges \\
\hline SD4 & AB1157 but $\Delta(\operatorname{srlR}-r e c A) 306:: \operatorname{Tn} 10$ & P1(RW202)xAB1157 \\
\hline SD5 & BS87 but $\Delta(\operatorname{srlR}-r e c A) 306:: \operatorname{Tn} 10$ & P1(RW202)xBS87 \\
\hline E. coli C-1 & wild type & CGSC \\
\hline BS159 & E. coli $C-1$ but alkB117::Tn3 & F148/BS87xE.coli C-1 \\
\hline CC101-CC106 & ara $\Delta(\text { lac proB })_{\mathrm{XIII}} / \mathrm{F}^{\prime} l a c I^{-} Z^{-}$pro $^{+}$ & Cupples and Miller 1989 \\
\hline SD11-SD16 & CC101-CC106 but alkB117::Tn3 & P1(BS87)xCC102-CC106 \\
\hline PT11 & 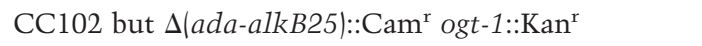 & Taverna and Sedgwick 1996 \\
\hline
\end{tabular}

All strains are E. coli K12 unless specified to be E. coli C.

alkB117::Tn3) was selected on M9 minimal agar containing carbenicillin without amino acid supplements.

\section{Preparation and titration of bacteriophage lysates}

Bacteria were grown in LB broth. Tetracycline was added for strains carrying the $\mathrm{F}^{\prime}$ proAB $B^{+}$lacI $I^{\mathrm{Q}}$ lacZ $\Delta M 15$ Tn10 factor. M13mp18 and $\mathrm{f} 1$ phage lysates of strain $\mathrm{AB} 1157 / \mathrm{F}^{\prime}$ and $\lambda_{\mathrm{gv}}$ lysates of AB1157 were prepared as described (Sambrook et al. 1989; Dinglay et al. 1998). G4 phage lysates were prepared using E. coli C-1. G4 phage $\left(2 \times 10^{4} \mathrm{pfu}\right)$ and $5 \mathrm{~mm} \mathrm{CaCl}_{2}$ were added to $1 \mathrm{ml} \mathrm{E}$. coli $\mathrm{C}-1$ culture $\left(\mathrm{A}_{600} 0.25\right)$ and incubated without shaking at $37^{\circ} \mathrm{C}$ for $10 \mathrm{~min}$. Thirty $\mathrm{ml} \mathrm{LB}$ broth containing $5 \mathrm{~mm}$ $\mathrm{CaCl}_{2}$ were then added and incubated for $6 \mathrm{hr}$. After adding 100 $\mu \mathrm{l}$ chloroform, the lysate was centrifuged at $7600 \mathrm{~g}$ for $10 \mathrm{~min}$, and the supernatant retained. To titer, M13, f1, and G4 phage were serially diluted and 100- $\mu$ l aliquots were plated with $100 \mu \mathrm{l}$ of late exponential cultures of host bacteria $\left(\mathrm{A}_{600} 0.8\right)$ in $3 \mathrm{ml}$ melted soft LB agar on LB agar plates and incubated overnight at $37^{\circ} \mathrm{C}$. Phage survival was monitored by plaque formation. Phage $\lambda$ were titered as described previously (Dinglay et al. 1998).

\section{Survival of bacteriophage after treatment with DNA-damaging agents}

MNU was dissolved in $10 \mathrm{~mm}$ potassium acetate $(\mathrm{pH} 4.5)$ and aliquots stored at $-20^{\circ} \mathrm{C}$. Phage lysates were diluted to $8 \times 10^{9}$ $\mathrm{pfu} / \mathrm{ml}$ in $\mathrm{M} 9$ minimal salts and $10 \mathrm{mM} \mathrm{MgSO}_{4}$ and mixed with an equal volume of methylating agent (MMS, DMS, MeI, or $\mathrm{MNU}$ ) freshly diluted to various concentrations in the same medium. After incubation at $30^{\circ} \mathrm{C}$ for $30 \mathrm{~min}$ (unless otherwise indicated), the phage suspensions were diluted immediately in M9 salts and $1 \mathrm{mM} \mathrm{MgSO}_{4}$ and titered for survival. M13 phage $\left(4 \times 10^{8} \mathrm{pfu} / \mathrm{ml}\right)$ exposed for various times to $\gamma$ irradiation emitted by a CSL $15-137$ Cs source at $2.71 \mathrm{~Gy} / \mathrm{min}$ were similarly titered for survival.

Transformation with MMS-treated M13 single-stranded or double-stranded DNA

Isolation of M13mp18 single-stranded DNA, preparation of competent cells by treatment with $\mathrm{CaCl}_{2}$, and transformation of these cells with M13 DNA were as described (Sambrook et al. 1989). To assay for pfu, AB1157 or BS87 (alkB117::Tn3) cells transformed with M13 DNA were plated in LB soft agar together with $\mathrm{AB} 1157 / \mathrm{F}^{\prime}$ or $\mathrm{BS} 87 / \mathrm{F}^{\prime}$, respectively. The frequency of transformation was assayed over several concentrations of single-stranded or double-stranded M13 DNA in order to define the linear range. In this range, 20 ng double-stranded DNA gave approximately 6000 transfectants and $100 \mathrm{ng}$ single-stranded DNA gave approximately 2000 transfectants. When treating with MMS, $1 \mu$ DNA (100 ng double stranded or 500 ng single stranded) was incubated with $1 \mu \mathrm{l}$ MMS at various concentrations in $\mathrm{M} 9$ minimal salts and $10 \mathrm{mM} \mathrm{MgSO}_{4}$ at $30^{\circ} \mathrm{C}$ for 30 $\mathrm{min}$. The MMS was diluted immediately by adding $18 \mu 110 \mathrm{~mm}$ Tris- $\mathrm{HCl}$ and $1 \mathrm{~mm}$ EDTA (pH 8). Four microliters of the treated DNA was added to $50 \mu \mathrm{l}$ competent cells to monitor the transformation frequency.

\section{Sensitivity of alkB mutants to MMS mutagenesis}

Strains CC101-CC106 (Miller 1992) and their alkB117::Tn3 derivatives were grown in $\mathrm{M} 9$ minimal salts media to $\mathrm{A}_{450} 0.5$. Aliquots were treated with various concentrations of MMS at $37^{\circ} \mathrm{C}$ for $20 \mathrm{~min}$, washed in $\mathrm{M} 9$ salts containing $1 \mathrm{mM} \mathrm{MgSO}_{4}$, and then serially diluted in the same buffer. Cells were plated on LB agar to estimate survival and on minimal media plates containing $0.2 \%$ lactose to monitor $\mathrm{Lac}^{+}$mutant colonies. The plates were incubated at $37^{\circ} \mathrm{C}$.

Sensitivity of exponential and stationary phase cells to MMS

Cells were cultured in M9 minimal media supplemented with $0.2 \%$ casein amino acid hydrolysate (Sigma-Aldrich) and thiamine hydrochloride (Miller 1992). Cultures were exposed to MMS either during exponential growth at $\mathrm{A}_{450} 0.5$ or $16 \mathrm{hr}$ after entering stationary phase at $\mathrm{A}_{450}$ 1.3. The MMS treatments were at $37^{\circ} \mathrm{C}$ for $20 \mathrm{~min}$, and the cells were immediately diluted and plated on LB agar plates to monitor cell survival.

\section{Subcloning of the alkB gene and purification of his-tagged AlkB protein}

Oligonucleotide primers were synthesized on an Applied Biosystems 394 DNA Synthesizer. The alkB gene in plasmid pCS70 
(Teo et al. 1984) was amplified by PCR, using Pfu polymerase (Stratagene) and two primers 5'-GGAGAGCATATGTTGGATCTGTTTGCCGAT-3' and 5'-ATTCGGATCCTTATTCTTTTTTACCTGCCT- $3^{\prime}$, to engineer NdeI and BamHI restriction sites at the $5^{\prime}$ and $3^{\prime}$ ends of the gene, respectively. The PCR product was digested with $\mathrm{NdeI}$ and $\mathrm{BamHI}$ and inserted into the vector pET15b (Novagen). The DNA sequence of the insert was verified to be correct by sequencing both DNA strands. The new construct, pBAR54, encoded the AlkB protein with a tag of six histidines attached to its amino terminus. This plasmid was transformed into BL21.DE3, in which expression of the cloned gene was induced by IPTG (Studier et al. 1990). SDS-PAGE and Western blotting using anti-AlkB polyclonal antibodies monitored induction of the AlkB protein.

BL21.DE3/pBAR54 was cultured in $270 \mathrm{ml} \mathrm{LB}$ broth and 50 $\mu \mathrm{g} / \mathrm{ml}$ carbenicillin to $\mathrm{A}_{600} 0.5$ at $37^{\circ} \mathrm{C}$. IPTG $1 \mathrm{~mm}$ was added and the incubation continued for $3 \mathrm{hr}$. The cells were harvested, washed in PBSA, and resuspended in $8.5 \mathrm{ml} 50 \mathrm{~mm}$ Hepes- $\mathrm{KOH}$ (pH 8) 2 mM $\beta$-mercaptoethanol, 5\% glycerol, and $300 \mathrm{~mm}$ $\mathrm{NaCl}$. After sonication, the extract was clarified by centrifugation. The extract (55 mg total protein) was supplemented with $1 \mathrm{~mm}$ imidazole and loaded onto a 1-ml Ni-NTA /nitrilotriacetic acid)-agarose column (Qiagen) previously equilibrated in buffer (50 mм Hepes-KOH at pH 8, 2 mm $\beta$-mercaptoethanol, $5 \%$ glycerol, $100 \mathrm{~mm} \mathrm{NaCl}, 1 \mathrm{~mm}$ imidazole). The column was washed with $20 \mathrm{ml}$ buffer and then $30 \mathrm{ml}$ buffer containing $40 \mathrm{~mm}$ imidazole followed by $5 \mathrm{ml}$ buffer containing $60 \mathrm{~mm}$ imidazole. The AlkB protein was eluted in buffer containing $250 \mathrm{~mm}$ imidazole. $\mathrm{A}_{280}$ readings and visualization by SDS-polyacrylamide gel electrophoresis located the fractions containing pure AlkB protein. The purified his-tagged AlkB protein $(1.9 \mathrm{mg})$ was dialysed into $30 \mathrm{~mm}$ potassium phosphate $(\mathrm{pH} 7.5), 2 \mathrm{~mm}$ DTT, 3 mM EDTA, $300 \mathrm{~mm} \mathrm{NaCl}$, and $50 \%$ glycerol and stored at $-80^{\circ} \mathrm{C}$.

\section{Binding of his-tagged AlkB protein to DNA}

A 40-mer oligonucleotide, 5' -AACGCTACTACTATTAGTAGAATTGATGCCACCTTTTCAG-3', was 5' phosphorylated using $\left[\gamma^{-32} \mathrm{P}\right] \mathrm{ATP}$ and T4 polynucleotide kinase (New England Biolabs). To prepare double-stranded DNA, the end-labeled oligonucleotide was annealed to a twofold excess of complementary strand by heating at $95^{\circ} \mathrm{C}$ for 2 min and cooling slowly to room temperature $(\sim 4 \mathrm{hr})$. Single- and double-stranded oligonucleotides were treated with $300 \mathrm{mM} \mathrm{MMS}$ at $30^{\circ} \mathrm{C}$ for $30 \mathrm{~min}$ and the MMS removed by centrifugation through a Sephadex G50 column equilibrated in $10 \mathrm{~mm}$ Tris- $\mathrm{HCl}$ and $1 \mathrm{~mm}$ EDTA (pH 8). Varying amounts of his-tagged $A l k B$ protein were incubated with $\left[{ }^{32} \mathrm{P}\right]-5^{\prime}$ end-labeled DNA oligomers $(30,000 \mathrm{cpm} /$ reaction) in $20 \mu l$ buffer $(20 \mathrm{~mm}$ Tris- $\mathrm{HCl}$ at $\mathrm{pH} 7.5,100 \mathrm{~mm} \mathrm{KCl}, 0.1 \mathrm{~mm}$ DTT, $10 \%$ glycerol) at $30^{\circ} \mathrm{C}$ for $30 \mathrm{~min}$. After addition of $1 \mathrm{ml}$ ice-cold buffer, the reaction mixture was immediately filtered through nitrocellulose disc filters (HAW P02500 Scheibenfilter, Millipore) using a vacuum filtration apparatus (Millipore). The filters were washed with $10 \mathrm{ml}$ of buffer and dried. Scintillation counting quantitated labeled DNA bound to AlkB protein.

\section{Acknowledgments}

We thank Lauren Posnick, Peter Karran, and Richard Wood for discussions and John Sguoros and Michael Mitchell for help with homology searches. This work was supported by the Imperial Cancer Research Fund.

The publication costs of this article were defrayed in part by payment of page charges. This article must therefore be hereby marked "advertisement" in accordance with 18 USC section 1734 solely to indicate this fact.

\section{References}

Abbott, P.J. and Saffhill, R. 1977. DNA synthesis with methylated (dA-dT) templates: Possible role of $\mathrm{O}^{4}$-methylthymine as a pro-mutagenic base. Nucleic Acids Res. 4: 761-769.

Aravind, L., Walker, D.R., and Koonin, E.V. 1999. Conserved domains in DNA repair proteins and evolution of repair systems. Nucleic Acids Res. 27: 1223-1242.

Ausubel, F.M., Brent, R., Kingston, R.E., Moore, D.D., Seidman, J.G., Smith, J.A., and Struhl, K. 1999. Current protocols in molecular biology. Wiley Interscience, New York, NY.

Banerjee, S.K., Borden, A., Christensen, R.B., LeClerc, J.E., and Lawrence, C.W. 1990. SOS-dependent replication past a single trans- syn T-T cyclobutane dimer gives a different mutation spectrum and increased error rate compared with replication past this lesion in uninduced cells. J. Bacteriol. 172: 2105-2112.

Bjelland, S. and Seeberg, E. 1996. Different efficiencies of the Tag and AlkA DNA glycosylases from Escherichia coli in the removal of 3-methyladenine from single-stranded DNA. FEBS Lett. 397: 127-129.

Boiteux, S. and Laval, J. 1982. Mutagenesis by alkylating agents: Coding properties for DNA polymerase of poly(dC) template containing 3-methylcytosine. Biochimie 64: 637-641.

Chen, B.J., Carroll, P., and Samson, L. 1994. The Escherichia coli AlkB protein protects human cells against alkylationinduced toxicity. J. Bacteriol. 176: 6255-6261.

Colombi, D. and Gomes, S.L. 1997. An alkB homolog is differentially transcribed during the Caulobacter crescentus cell cycle. J. Bacteriol. 179: 3139-3145.

Cupples, C.G. and Miller, J.H. 1989. A set of lacZ mutations in Escherichia coli that allow rapid detection of each of the six base substitutions. Proc. Natl. Acad. Sci. 86: 5345-5349.

Dinglay, S., Gold, B., and Sedgwick, B. 1998. Repair in Escherichia coli alkB mutants of abasic sites and 3-methyladenine residues in DNA. Mutat. Res. 407: 109-116.

Kataoka, H., Yamamoto, Y., and Sekiguchi, M. 1983. A new gene $(a l k B)$ of Escherichia coli that controls sensitivity to methyl methane sulfonate. J. Bacteriol. 153: 1301-1307.

Kondo, H., Nakabeppu, Y., Kataoka, H., Kuhara, S., Kawabata, S., and Sekiguchi, M. 1986. Structure and expression of the alkB gene of Escherichia coli related to the repair of alkylated DNA. J. Biol. Chem. 261: 15772-15777.

Kornberg, A. and Baker, T.A. 1992. DNA replication. W.H. Freeman, New York, NY.

Landini, P., Hajec, L.I., and Volkert, M.T. 1994. Structure and transcriptional regulation of the Escherichia coli adaptive response gene aid B. J. Bacteriol. 176: 6583-6589.

Larson, K., Sahm, J., Shenkar, R., and Strauss, B. 1985. Methylation-induced blocks to in vitro DNA replication. Mutat. Res. 150: 77-84.

Lindahl, T., Karran, P., and Wood, R.D. 1997. DNA excision repair pathways. Curr. Opin. Genet. Dev. 7: 158-169.

Lindahl, T., Sedgwick, H., Sekiguchi, M., and Nakabeppu, Y. 1988. Regulation and expression of the adaptive response to alkylating agents. Annu. Rev. Biochem. 57: 133-157.

Mackay, W.J., Han, S., and Samson, L.D. 1994. DNA alkylation repair limits spontaneous base substitution mutations in Escherichia coli. J. Bacteriol. 176: 3224-3230.

Matijasevic, Z., Sekiguchi, M., and Ludlum, D.B. 1992. Release of $\mathrm{N}^{2}$, 3-ethenoguanine from chloroacetaldehyde-treated DNA by Escherichia coli 3-methyladenine-DNA glycosylase 
II. Proc. Nat1. Acad. Sci. 89: 9331-9334.

Miller, J.H. 1972. Experiments in molecular genetics. Cold Spring Harbor Laboratory Press, Cold Spring Harbor, NY.

- 1992. A short course in bacterial genetics. Cold Spring Harbor Laboratory Press, Cold Spring Harbor, NY.

Pegg, A.E., Dolan, M.E., and Moschel, R.C. 1995. Structure, function, and inhibition of $\mathrm{O}^{6}$-alkylguanine-DNA alkyltransferase. Prog. Nucleic Acid Res. Mol. Biol. 51: 167-223.

Rebeck, G.W. and Samson, L. 1991. Increased spontaneous mutation and alkylation sensitivity of Escherichia coli strains lacking the ogt $\mathrm{O}^{6}$-methylguanine-DNA methyltransferase. J. Bacteriol. 173: 2068-2076.

Saffhill, R. 1984. Differences in the promutagenic nature of 3-methylcytosine as revealed by DNA and RNA polymerising enzymes. Carcinogenesis 5: 691-693.

Sambrook, J., Fritsch, E.F., and Maniatis, T. 1989. Molecular cloning: A laboratory manual. Cold Spring Harbor Laboratory Press, Cold Spring Harbor, NY.

Saparbaev, M. and Laval, J. 1994. Excision of hypoxanthine from DNA containing dIMP residues by the Escherichia coli, yeast, rat, and human alkylpurine DNA glycosylases. Proc. Nat1. Acad. Sci. 91: 5873-5877.

Schendel, P.F. and Defais, D. 1980. The role of umuC gene product in mutagenesis by simple alkylating agents. Mol. Gen. Genet. 177: 661-665.

Sedgwick, B. 1982. Genetic mapping of $a d a$ and $a d c$ mutations affecting the adaptive response to Escherichia coli to alkylating agents. J. Bacteriol. 150: 984-988.

1992. Oxidation of methylhydrazines to mutagenic methylating derivatives and inducers of the adaptive response of Escherichia coli to alkylation damage. Cancer Res. 52: 3693-3697.

Singer, B. and Grunberger, D. 1983. Molecular biology of mutagens and carcinogens. Plenum Press, New York, NY.

Studier, F.W., Rosenberg, A.H., Dunn, J.J., and Dubendorff, J.W 1990. Use of T7 RNA polymerase to direct expression of cloned genes. Methods Enzymol. 185: 60-89.

Taverna, P. and Sedgwick, B. 1996. Generation of an endogenous DNA-methylating agent by nitrosation in Escherichia coli. J. Bacteriol. 178: 5105-5111.

Teo, I., Sedgwick, B., Demple, B., Li, B., and Lindahl, T. 1984. Induction of resistance to alkylating agents in E.coli: The $a d a^{+}$gene product serves both as a regulatory protein and as an enzyme for repair of mutagenic damage. Embo J. 3: 21512157.

Vaughan, P., Sedgwick, B., Hall, J., Gannon, J., and Lindahl, T. 1991. Environmental mutagens that induce the adaptive response to alkylating agents in Escherichia coli. Carcinogenesis 12: 263-268.

Volkert, M.R. and Hajec, L.I. 1991. Molecular analysis of the aidD6::Mud1(bla lac) fusion mutation of Escherichia coli K12. Mol. Gen. Genet. 229: 319-323.

Wei, Y., Carter, K.C., Wang, R., and Shell, B.K. 1996. Molecular cloning and functional analysis of a human cDNA encoding an Escherichia coli AlkB homolog, a protein involved in DNA alkylation damage repair. Nucleic Acids Res. 24: 931937. 


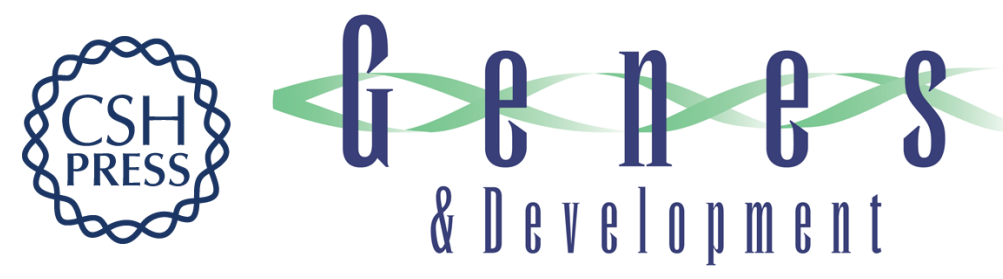

\section{Defective processing of methylated single-stranded DNA by $E$. coli alkB mutants}

Suneet Dinglay, Sarah C. Trewick, Tomas Lindahl, et al.

Genes Dev. 2000, 14:

Access the most recent version at doi:10.1101/gad.14.16.2097

References

This article cites 30 articles, 14 of which can be accessed free at: http://genesdev.cshlp.org/content/14/16/2097.full.html\#ref-list-1

\section{License}

Email Alerting

Receive free email alerts when new articles cite this article - sign up in the box at the top Service right corner of the article or click here.

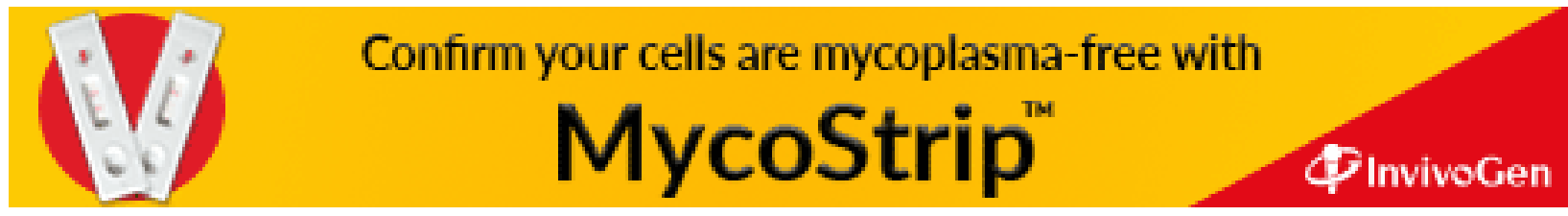

